Social Dynamics

\title{
Clearing the ground: Spurious attacks and genuine issues in the debate about philosophy in a post-colonial society
}

\section{André du Toit}

To cite this article: André du Toit (1995) Clearing the ground: Spurious attacks and genuine issues in the debate about philosophy in a post\#colonial society, Social Dynamics, 21:1, 33-70, DOI: $10.1080 / 02533959508458579$

To link to this article: http://dx.doi.org/10.1080/02533959508458579

曲 Published online: 16 May 2008.

Submit your article to this journal $[\pi$

Џll Article views: 20

Q View related articles ¿

Citing articles: 1 View citing articles ¿ 


\title{
Clearing the Ground: Spurious Attacks and Genuine Issues in the Debate about Philosophy in a Post-Colonial Society
}

\author{
André du Toit \\ Department of Political Studies \\ University of Cape Town
}

\section{One}

For anyone somewhat in touch with the philosophical community in South Africa it must come as a surprise to learn that analytical philosophy has been under attack, and needs to be defended against its "critics". The very idea of attacking or defending "analytical philosophy" now seems strange and dated; a generation or two ago there was no lack of critics, nor of defences and counterattacks, but much has changed in the philosophical world since then.

There was a time when analytical philosophy was more controversial, both abroad and in the local South African situation. Logical positivism had a definite programmatic aspect and the young Freddy Ayer delighted in spelling out its radical implications in Language, Truth and Logic (Ayer 1936). Other erstwhile members of the Vienna Circle vigorously pursued the ideals of "unified science" at major teaching universities in the United States. In a different way Popper aligned his notion of the open society to the conflict with fascism and totalitarianism while his approach to the logic of scientific discovery was taken up and extended by new generations of philosophers and scientists alike. After the Second World War analytical philosophy for a while achieved a certain hegemony, with the linguistic philosophy of the later Wittgenstein and J.L.Austin making an especially marked impact. This was the time when Oxford became a sort of philosophical capital of the world, attracting considerable numbers of able and ambitious young philosophers from America and elsewhere who went on to become leading figures in contemporary philosophy. Even into the 1970s analytical philosophy retained a certain programmatic aspect, though by then leading figures such as Quine and Davidson were located in the United States. 
However, over the last two decades much has changed on the philosophical scene; in various ways the era of "post-analytical philosophy", to cite the title of an influential book edited by Comel West and other younger philosophers (Rajchman and West 1985), has arrived. This does not mean that analytical philosophy has been superceded; indeed, in one form or another it remains the mainstream orientation in contemporary philosophy in the English-speaking world and even beyond. But this has long since ceased to be controversial; analytical philosophy is accepted as part of the furniture, so to speak. At the same time the dividing lines between analytical philosophy and its rivals or opponents have become much more blurred. Richard Rorty, once the editor of The Linguistic Turn (Rorty 1967), a standard collection of key texts of analytical philosophy, went on to become a leading figure of deconstructionism, while more generally the impact of postmodemist philosophy served to diminish the preoccupations with the more programmatic and methodological aspects of analytical philosophy that had characterised an earlier era. Jon Elster, Gerry Cohen and others have reinterpreted Marx and Marxism in analytical vein, leading to a distinct school of "analytical Marxism". Even such renowned "obscurantist" philosophers as Hegel and Heidegger have been the object of considerable analytical work and interest, so that these days it is hard to tell where the boundaries between analytical and nonanalytical philosophy are to be found.

In any case, nowadays it seems of lesser importance whether such boundaries can be drawn, and much of the fun has gone out of comparing analytical philosophy to its philosophical rivals given the more general crisis facing the discipline of philosophy itself. In England, and elsewhere too, philosophy has fallen on hard times. It has been especially hard hit by the Thatcherite rationalisation of the universities, with philosophy departments, too, having to justify their continued existence in market-related terms. Oxford is no longer the kind of philosophical centre it used to be; many of its leading figures have taken up positions elsewhere and it is no longer automatically attracting the best young philosophical minds of the coming generation. Increasingly philosophers are looking to fields like applied ethics for their future prospects. In these developments, too, analytical philosophy has had an important part to play, and will no doubt continue to do so - that much is uncontroversial - but that does not mean that the "relevance" of analytical philosophy in particular is at all a pressing concem. On the contrary, the issues run both wider and deeper than the concerns of an essentially inward-looking philosophical rivalry. 
In the South African context, too, a similar story could be told. A generation ago the dividing lines between analytical and non-analytical philosophers were much more sharply drawn. Some philosophy departments at Afrikaans universities continued to practice a more traditional approach to philosophy in terms of "life and world views" of a more metaphysical bent or aligned to different religious and cosmological perspectives. In general the Afrikaans philosophy departments tended to be oriented towards "Continental" traditions, while their counterparts at the University of Cape Town or the Witwatersrand were more attuned to the AngloSaxon world, though this did not necessarily mean that it took the form of analytical philosophy (at UCT, for example, as late as the early 1970s the senior positions in the Philosophy Department were still held by Andrew Murray, Martin Versfeld and S.I.M.du Plessis, hardly a trio of analytical philosophers). The impact of analytical philosophy came relatively late, and it was really only from the $1960 \mathrm{~s}$ that the Meyers at Unisa, Jonathan Suzman at Wits and especially Daantjie Oosthuizen at Rhodes established a strong analytical presence on the South African philosophical scene. To begin with, that presence was decidedly controversial; analytical philosophers had to contend not only with more traditional approaches to philosophy, but also with colleagues strongly committed to rival new approaches such as phenomenology (and/or existentialism) and even, occasionally, (Neo)Marxism.

In this context polemical exchanges and programmatic or methodological discussions tended to proliferate; analytical philosophers explicitly and implicitly developed strong critiques of rival philosophical approaches, and they in turn had their critics. These philosophical differences were compounded by the political and ideological conflicts of an apartheid society, so that the South African philosophical community was quite strongly polarised. It was only with difficulty that a common professional organisation for philosophers could be founded by the late 1960 s, and even then there was a marked difference between the annual congresses of the South African Philosophical Society, which somehow made room for many different philosophical persuasions, and the more informal "Spring Colloquia" where mainly analytical philosophers gathered. It was a well-known fact of life that there were philosophy departments where analytical philosophers were not welcome, and vice versa.

It is with some relief that one can say that this is no longer an accurate description of the South African philosophical scene, and has not been that for quite some time. Here, too, the philosophical community is much less polarised and 
in different ways the dividing lines have become much more blurred. These days more or less analytically trained philosophers can be found in Afrikaans and other philosophy departments as well, while Rhodes for a number of years made a place for a Calvinist philosopher and at Wits Foucault is taught as part of the regular curriculum. The South African Journal of Philosophy typically carries an eclectic mix of articles with analytical contributions rubbing shoulders with less or nonanalytical articles (Philosophical Papers, by contrast, is self-consciously a journal of analytical philosophy in a fairly pronounced sense, but hardly functions in the South African context: it is in effect an international journal which so happens to be published at Wits). In South Africa, too, postmodernism and deconstruction have had an impact in shifting attention away from more methodological and programmatic preoccupations, though that impact has been greater outside philosophy departments than within them. ${ }^{1}$ Perhaps the one department which still has a markedly "analytical" identity is the Philosophy department at UCT. The more significant developments and initiatives of recent years, such as Johan Mouton's Methodology and Interdisciplinary Philosophy Programmes at the HSRC or the founding of the Social Theory group, can not really be characterised in analytical or non-analytical terms. Similarly the more successful workshops of the last few years, such as those organised in conjunction with the visits of John Thompson and Charles Taylor, typically involved philosophers who cut across any remaining lines between analytical and non-analytical philosophy.

All of this does not mean that philosophy in South Africa is flourishing; on the contrary, here, too, philosophy has fallen on increasingly hard times and warning lights are flickering. In 1995, for the first time in four decades, the annual Philosophy Congress had to be cancelled, and meetings of the "Spring Colloquia" have also become more sporadic and unfocused. Some philosophy departments, including UCT, have experienced difficulties in filling chairs; in other cases the indications are that chairs may well not be filled at all. In general, philosophy departments are facing major problems connected with the rapidly changing nature of the student body at South African universities, combined with the increasing pressures on scarce resources in the university context. In the South Africa of the 1990s philosophers are hard pressed to justify a continuation of the central place which philosophy used to lay claim to in the university; it is not too much to say that, unless appropriate changes in the location, curriculum and methods of teaching can be found which relate to the current political context and job market, this traditional role may well be at risk. In short, philosophy in South Africa is 
facing a real crisis - but one that has little or nothing to do with the lines dividing analytical philosophers from their non-analytical colleagues; the programmatic battles which once raged amongst them have long since lost any remaining urgency.

So how does one understand and explain Denise Meyerson's account (Meyerson this volume) ${ }^{2}$ of an embattled analytical philosophy in need of defence against its hostile and uninformed critics? For this is the central contention and abiding preoccupation of an otherwise excellent paper. Meyerson has much to say that is of genuine interest about the current state of philosophy, but it is unfortunately all pressed into service for a spirited defence of analytical philosophy against its philosophical rivals as well as popular prejudice and misconceptions. At first blush it is tempting to see this as an anachronistic curiosity, a resurrection of the polemics of yesteryear by a belated protagonist who is blithely unaware of the fact that the caravan has long since moved on. Nor is Meyerson's version of the "critics" of analytical philosophy calculated to convince one of the gravity of any threat posed by them. Her evidence for this "attack" effectively consists of an article by Robert Paul Wolff from 1986 (Wolff 1986-7) and some scattered writings by myself as critic-in-chief. The piece by Wolff was an impressionistic account based on his experience of some South African philosophy departments during a visit in that year. It certainly presented a rather jaundiced view of the state of philosophy in South Africa at the time, coloured by Wolff's personal perspective on the anti-apartheid struggle and the academic boycott. If an answer to this broadside was needed, it has been provided by Seumas Millar and Ian MacDonald and also published in The Philosophical Forum in 1990 (Miller and MacDonald 1990). There does not seem any pressing need to revive this particular polemic at the present time. This leaves myself as the main and, in effect, sole "critic" against whom analytical philosophy has to be defended. The evidence here consists of a paper originally written as long ago as 1976 (du Toit 1982), my inaugural lecture of 1988 (du Toit 1988a) and a contribution to a 1987 workshop on "Philosophy in South Africa" that was never even published (du Toit 1987). It can easily be ascertained that neither of the published papers dealt specifically with analytical philosophy or set out to develop a serious critique of it, though en passant they certainly contained critical remarks of various kinds, as they did of many other aspects of philosophy in South Africa as well.

That, then, appears to be the sum of the purported attack on analytical philosophy in South Africa, at least on Meyerson's own account: a polemical 
broadside by an American philosopher passing through some years ago (and which has long since been rebutted by others), and some critical remarks made in passing by myself, in one case almost a decade ago, and in the other case going on for twenty years ago. This hardly amounts to anything like an urgent threat or a concerted attack. Meyerson repeatedly refers to "popular" misconceptions about the nature of analytical philosophy, and to critical views "common enough in South African academic circles" (Meyerson, this volume:1). This sounds like par for the course, and no particular reason for undue concem. Certainly Meyerson gives no indication why these "popular" prejudices and misconceptions have suddenly become of more consequence, nor does she make any serious attempt to uncover their sources or to show why and how they are likely to do clamage. It is to the views and arguments of her two "critics", Wolff and du Toit, that she devotes all her defensive efforts. In short, on the face of it there is no clear need to mount a defence of analytical philosophy at this time or against these particular "critics".

The puzzle deepens if we consider who and what Meyerson purports to be defending. I suppose it is conceivable that there might still be some old-fashioned analytical philosophers around who, in defiance of more general changes in the philosophical climate, remain committed to the verificationist principle, or perhaps to the Quine/Davidson programme, to the exclusion of anything else as philosophy proper. Such "purist" and hardline analytical philosophers wculd certainly have cause to feel embattled in a context where eclectic postmodernists are let loose, while others press for philosophy to be made relevant to the South African context and/or to develop programmes of applied ethics, etc. They would also have good reason to take my critical strictures in the papers cited by Meyerson as applicable to their own position. But according to her paper this is not Meyerson's own view of analytical philosophy. She takes pains to reject any insular or monolithic approach to analytical philosophy, instead stressing its continuities with the classical mainstream of philosophy as well as the need to be open to other traditions and disciplines. Indeed, she offers a rather attractive and open-minded conception of analytical philosophy in particular, and more generally of the task of philosophy in the South African context. This is a conception of analytical philosophy which I, for one, would have no difficulty in endorsing. Indeed, in some respects it is in line with the views in precisely those papers of mine cited by her. Certainly, on this conception of it, one must wonder how anyone could possibly object to analytical philosophy, except perhaps some atavistic positivist, or perhaps a radical deconstructionist. 
So just who are the South African analytical philosophers Meyerson is defending? On a narrow interpretation of analytical philosophy, this would probably include a handful of philosophers mainly at Wits, Rhodes and UCT. On a more inclusive interpretation, though, such as that professed by Meyerson herself, the range could be considerably larger, perhaps even including myself. On this view, my own critical remarks would then appear in a different light, not as an attack by a "critic" of analytical philosophy as such, but as part of an intemal debate among, and with, analytical philosophers.

There is a further possibility - that Meyerson is not entirely consistent or open about her identification of analytical philosophy and tends to shift between its narrower and more inclusive interpretations according to the needs of her argument. Thus she could view herself as belonging to the small handful of "purist" analytical philosophers in South Africa who might well feel a need for a defence of some kind against their "critics", real or imagined. But when it comes to an explicit characterisation she invokes the catholic and non-monolithic description of analytical philosophy which, if at all serious, would obviate any need for defence since it would already encompass the purported "critics". If so, then this will not do at all: if a narrow and "purist" conception of analytical philosophy might well be in need of a defence, then this cannot be achieved by the sleight of hand of shifting the ground to a more catholic and relaxed definition of analytical philosophy itself. And if she is serious about that more inclusive definition of analytical philosophy, then this must apply both to her own practice as well as to her dealings with the purported "critics" of analytical philosophy.

Either way there is ample ground for a closer analysis of Meyerson's paper. I would not like simply to charge her with the transparent ploys of inventing "critics" of analytical philosophy in South Africa when they no longer exist, and then to mount a defence of analytical philosophy in the name of an inclusive and catholic conception of it when what is really at stake is a rearguard action on behalf of a rather different and beleaguered little group of analytical purists. We need to look more closely at just what is involved in her characterisation of analytical philosophy, and then we need to test this in various ways. On the one hand we need to see how this characterisation would apply to the track record of such purported "critics" of analytical philosophy as myself. And on the other hand we need to see to what extent her own practice in this article, i.e. her account of the positions of the purported "critics" of analytical philosophy, actually exemplifies a narrower or a more relaxed conception of analytical philosophy itself. The proof of the pudding 
is in the eating of it, and there can be no better test of the sincerity of Meyerson's profession of an inclusive and relaxed conception of analytical philosophy than to see whether she practices what she preaches when she attempts to give an account of the purported "critics" of analytical philosophy. Still, all this is not merely a matter of possibly catching her out; explicitly and by implication Meyerson's article raises a number of critical issues regarding the current state and the possible role of philosophy in South Africa which go well beyond just the question of analytical philosophy. These substantive issues need to be properly addressed, but that can hardly happen as long as a series of misunderstandings and misrepresentations, both of analytical philosophy itself and of its "critics", get in the way. The purpose of this reply is thus not simply polemical; rather it aims to clear the way for the kind of substantive discussion which is actually needed.

I propose to proceed in the following way. First I will briefly reconstruct Meyerson's account of analytical philosophy as well as of the dilemmas and challenges faced by philosophers in the South African context. Secondly I will then provide something in the way of an intellectual autobiography, especially regarding my own relation to analytical philosophy, as a test case of sorts for Meyerson's characterisation of analytical philosophy. I will argue that on her own criterion, so far from being a hostile and uninformed "critic" of analytical philosophy, there should be little difficulty in accommodating me within the fold of this more catholic and relaxed conception of analytical philosophy. In tum this will lead on to the question how Meyerson could have arrived at such a systematic and wholesale misrepresentation of my own position, and have done so on the basis of some of my own writings. This will involve a critical assessment of her philosophical practice, at least in the present paper, and thus provide a different kind of test case of her professed conception of analytical philosophy. Finally, once the misunderstandings have been removed and the misrepresentaticns set straight, we can retum to the substantive questions conceming the dilemmas and challenges of (analytical) philosophy in the South African context. This should surely be the main business, but on this occasion we unfortunately cannot take it up directly.

\section{Two}

Consider first the rather attractive and open-minded conception of analytical philosophy in particular, and more generally of the task of philosophy in the South African context, provided in Meyerson's paper. Meyerson takes pains to distance herself from any narrow or purist conception of analytical 
philosophy. She strongly insists that analytical philosophy should by no means be confused with the programmatic doctrines of logical positivism or with the special preoccupations of ordinary language analysis which happened to be influential at earlier stages of the 20th century. On her account analytical philosophy is a broad church encompassing quite different kinds of philosophical work done in the Anglo-American world; it can be represented by philosophers otherwise as different as Russell, Camap, Putnam, Quine, Davidson, Rawls and Dworkin and it has no difficulty in finding allies among linguists like Chomsky. In truth, "analytic philosophy is merely the continuation in the twentieth century of a tradition which goes back to the Greeks" (Meyerson this volume:15); as such it can legitimately lay claim to the mainstream heritage of Plato, Aristotle, Descartes, Leibniz, Hume and Kant, while the easiest way to bring out its distinctive features is to reflect briefly on the Socratic method (Meyerson this volume:15f). Meyerson thus clearly rejects any "monolithic conception" of analytical philosophy, and accepts the implication that there can be no sharp divide between analytical and non-analytical philosophy.

Moreover, Meyerson accepts the challenge that (analytical) philosophy, thus broadly conceived, should engage with local and concrete issues arising from the society in which it is practised. Categorically she states that

it would be a poor form of philosophy which had nothing interesting to say about the society in which it is practised, and which was incapable of contributing positively to social transformation (Meyerson, this volume:9).

And again:

philosophy should illuminate matters of local importance, and a refusal or inability to reflect on the particular historical circumstances we inhabit would seriously impoverish our philosophy (Meyerson this volume:22).

On her understanding of the nature of analytical philosophy it should be clear how and why philosophy can and should take on these tasks, she contends, since it is a major insight of mature analytical philosophy that, contrary to verificationist dogmas, there is "no clear way to separate conceptual and empirical investigations", thus opening the way for "concrete" applications of philosophical explorations of meaning (Meyerson this volume:9). Since all philosophising involves the exploration of meanings, not only at verbal level but as a systematic and critical questioning of the assumptions of prevailing 
beliefs, it constitutes "an enterprise...with enormous potential to alter substantive beliefs" (Meyerson this volume:14). In this way Meyerson sees her own task in terms of

demonstrating just how satisfyingly analytical philosophy can engage with social and political issues, and have an impact on the world (Meyerson this volume:14).

Moreover, she recognises that the particularities of the South African context poses special problems in this regard:

The fact is that all South African social theorists and philosophers, of whatever persuasion, are working in the same context and face the same problem: we depend inevitably on overseas work and we need to be sensitive to the problems created by that (Meyerson this volume:28).

In short, Meyerson proposes a catholic and inclusive conception of analytical philosophy; it is important to her that philosophy thus conceived can and should be made "relevant" to social and political practices, and might even contribute to "social transformation"; and she recognises that the South African context poses some special problems in this regard. Broadly speaking, this is an approach which should fit quite comfortably with my own background and track record as a South African philoscpher, as the next section may briefly show.

\section{Three}

The extent to which I would consider myself an "analytical philosopher" has never been a particular concern to me; it would very much depend on the way in which this term is defined. Certainly, on some of the more narrow and purist conceptions of analytical philosophy I would never qualify. But on a conception as catholic and non-monolithic as that espoused by Meyerson, I should have no problems: analytical philosophy in this sense has been part and parcel of my training, research, teaching and writing for more than three decades. A brief survey of my own philosophical career could thus provide something of a test case for Meyerson's relaxed conception of analytical philosophy, and may also throw some light on the ways in which the local philosophical scene has changed during that time.

It would be incorrect to claim that contemporary analytical philosophy featured prominently in my initial undergraduate training in philosophy at Stellenbosch in the late 1950s. On the other hand, our curriculum at the time was solidly grounded 
in precisely that mainstream tradition of classical philosophy, with Socrates and Kant providing the key reference points, which Meyerson invokes. My Master's dissertation was on Kierkegaard, but this did not so much concern the protoexistentialist philosopher as it did the Kierkegaard of The Concept of Dread (Kierkegaard 1957), the rigorous analyst of fundamental conceptual categories harking back to the Kantian roots of Hegel. Around this time I was impressed by a visit to Stellenbosch by Daantjie Oosthuizen, then in the process of reinvigorating the Philosophy Department at Rhodes and beginning to make analytical philosophy a stronger presence in the South African context than hitherto. What impressed me about Oosthuizen was not only his masterly demonstration of a more rigorous analytical approach to the core problems of philosophy, but also the fusion of this with the classic Socratic spirit. I was especially intrigued by the way in which he applied these rigorous analytical techniques to current problems of South African politics and ideology, critically dissecting Piet Meyer's Broederbond philosophy or the conceptual logic of apartheid rationalisations. His untimely death was a major blow to the development of analytical philosophy in South Africa, but to my mind he demonstrated from the outset that there need not be any problem in applying analytical philosophy in "relevant" ways to South African issues.

For my graduate training in philosophy I went to Leijden University in the Netherlands. My main purpose was to find a doctoral programme where I could be exposed to the Continental traditions in philosophy as well as to the increasingly important developments in Anglo-American analytical philosophy. This worked well, and I was able to study with Van Peursen as well as with Nuchelmans, long the foremost exponent of analytical philosophy in the Netherlands and especially well versed in Camap's semantic methods and J.L.Austin's theory of speech acts. The topic of my Ph.D. dissertation was a comparison of the logical philosophy and methods of the early Bertrand Russell with those of the founding father of phenomenology, Edmund Husserl. The rationale for this project was precisely that it entailed a comparative study of the shared assumptions and common starting points of the respective methods which later became the hallmarks of analytical philosophy and the phenomenological movement. In common with the methodological preoccupations of philosophy at that time, I thus attempted to construct the basis for a programmatic comparison of analytical philosophy with phenomenology, though this was essentially conceived as a constructive enterprise rather than as any kind of hostile critique. In part this concerned highly abstract and technical issues in logical philosophy, such as Russell's theories of denoting 
and of definite descriptions, leaving me in no uncertainty as to how such apparently trivial matters as the precise meaning and assumptions involved in the use of a word like "the" could be of fundamental importance to philosophy in a wide range of different fields and applications. This work in a sense provided my point of entry as a professional philosopher: my first paper at a Philosophy Congress, and later my first article published in Philosophical Papers, was on "Logic and ontology: Russell's logical methods for philosophy prior to 1905" (du Toit 1974). And when the South African Journal of Philosophy was founded some years later, one of the early issues published my paper on "The critique of psychologism" drawn from the same research project (du Toit 1983).

Following my appointment to the Department of Political Philosophy at Stellenbosch in 1969 my main teaching and research interests focused on political and moral philosophy, with a strong emphasis on the implications and applications of these in the South African context. However, this did not mean anything like an exclusive specialisation in these particular sub-disciplines only. Due to the peculiar set-up at Stellenbosch University the Department of Political Philosophy actually functioned as a second Philosophy Department, responsible for a full complement of undergraduate and postgraduate programmes. In practice this meant that for many years I was responsible for teaching undergraduate courses in logic, in theory of meaning and philosophy of language, in methodology and the philosophy of science - in fact for a curriculum typical of an Anglo-American philosophy department. In a sense the Political Philosophy Department at Stellenbosch functioned as the local representative of analytical philosophy, and in the small world of South African philosophy we were quite naturally more closely aligned to the departments at Rhodes, Wits and UCT than to the other Afrikaans universities. The basis for this approach was precisely the conviction, which Meyerson also expresses in her paper, that political philosophy could not be taught as a selfcontained field of specialisation, but had to be firmly rooted in the core disciplines of mainstream philosophy. I am sure that in the eyes of university administrators the results may well have appeared anomalous: what was a course on Wittgenstein doing in the Honours programme of Political Philosophy or, for that matter, even a Masters dissertation on Quine? I happened to be responsible for both cases, and I can only say that in terms of my understanding of philosophy and of political philosophy I could not see how there could be any problem with this.

When it came to political philosophy itself, our approach was again firmly rooted in the methods and literature of analytical philosophy. Over many years 
(and to this day in the Department of Political Studies at UCT) my teaching has been based on introducing students at an early stage to elementary logical analysis and to the method of independent conceptual analysis, broadly derived from Wittgensteinian assumptions regarding ordinary usage. The idea was (and remains) that this would equip students with the basic analytical skills needed to deal with the literature on central political concepts (including many of the standard analyses produced by political philosophers working in the analytical tradition) in the core courses on political philosophy. The kind of textbook used as the basis for intermediate courses was Flathman's Concepts in Social and Political Philosophy, about as mainstream in analytical philosophy as one could get (Flathman 1973). At more advanced levels I developed courses specifically focused on the foundations of political and social theory in the analytical philosophy of language and theories of meaning. Thus for a number of years from the mid-1970s I taught a course on "Analytical Social and Political Philosophy" using Pitkin's Wittgenstein and Justice (Pitkin 1972), Winch's Idea of a Social Science (Winch 1958) and similar works to develop a Wittgensteinian approach to political philosophy. Apart from this, more standard courses on Rawls and Dworkin, or more generally on theories of justice and rights, as well as survey courses in political philosophy, were regular fare both at undergraduate and Honours level. ${ }^{3}$

My teaching was certainly not confined to analytical philosophy. I regularly taught foundation courses on Hegel and Marx, as well as occasional courses on critical theory, Habermas etc. I also worked hard on developing some courses which are not usually to be found in analytically oriented philosophy departments, in particular on South African intellectual and political history. In my Stellenbosch days this was still largely based on my own research on the history of Afrikaner political thought, but subsequently at UCT this has developed into a broad survey of the history of South African political thought and traditions. It is a feature of this course that local intellectual traditions are consistently located within more general comparative perspectives and grounded in basic theoretical and methodological approaches. My other special concem has been to develop a more applied approach to political philosophy, especially to problems of political morality. But this has consistently been done with specific reference to the nature of basic approaches in moral theory, such as deontology and utilitarianism, and has actually proved to be in line with a growing interest in applied ethics within analytical philosophy over the last decade and more. I would have thought that these "special interests", thus grounded in the core philosophical areas, are entirely compatible 
with the catholic and non-monolithic conception of an arlalytical philosophy sensitive to its South African context which Meyerson professes.

When it comes to research and publications, the story is not so different. I would not be able to say that the major thrust of my own research and publications has been in the more theoretical reaches of "pure" analytical philosophy, and certainly a great deal of my efforts have been concerned with applied work on South African politics and in allied fields such as intellectual history and democratic theory. But I have never seen this as a separate field of specialisation different from or unrelated to (analytical) philosophy. On the contrary, I have consistently sought to bring the methods and resources of philosophy, most decidedly including those of analytical philosophy, to bear in such research and applied work. Thus my work in the field of intellectual history has consistently and consciously sought to ground applied analyses in appropriate theoretical and philosophical frameworks. For these I have looked, for example, to the work of Quentin Skinner (Tully 1988), which in tum is based on J.L.Austin's speech act theory (see, for example, my paper on "Legitimate anachronism as a problem for intellectual history and philosophy"; du Toit 1991a). Similarly, in my work on the analysis of ideological discourse I have relied on John Thompson's work on the theory of ideology (Thompson 1984; du Toit 1994). ${ }^{4}$ I have also had no problem in venturing repeatedly into more direct explorations of analytical political philosophy. Thus I have given a number of papers on Rawls and the theory of justice at philosophical conferences and symposia over the years. And if Meyerson points to the importance of Dworkin for bringing out the logic of rights discourses in the South African context, then I may be allowed to recall that I devoted a whole series of papers over a number of years to precisely this topic. It: may be instructive to compare her comments in this regard with, for example, my chapter in Hugh Corder's Essays on Low and Social Practice (du Toit 1988b). Similarly my attempts to apply a Dworkinian analysis of rights in the context of medical ethics is just the sort of more "concrete" work to which she refers as typical of contemporary analytical philosophy (Meyerson this volume:8).

In short, I have for many years been practising in my teaching, research and publications precisely the sort of approach which Meyerson proposes as in accordance with her conception of analytical philosophy in the South African context. If she is serious about the inclusive and relaxed conception of analytical philosophy she professes in her paper, then she should have no difficulty in including me in the analytical fold thus conceived. Instead, she casts me as 
essentially a hostile "critic" of analytical philosophy, and an outdated and uninformed one to boot. On the other hand, if Meyerson, despite her professed catholic and non-monolithic conception of analytical philosophy and philosophers, actually subscribes to a more purist conception of analytical philosophy, one that will have no truck with philosophers who wander from the narrow and beaten tracks of rigorous analysis and that instinctively consider them a threat, then my typecasting as "critic" becomes somewhat more intelligible.

For my own part, I hope it will be clear enough from the above that, given my sustained endeavours as a philosopher over many years, I could not possibly hold the kind of views Meyerson attributes to me as a "critic" of analytical philosophy (unless I was the victim of an especially drastic case of intellectual schizophrenia). Confronted with these attributions, I have no hesitation in disavowing every single one of them as they stand, and if the position of the "du Toit" in her paper is taken to be mine, then I reject it as a total and utter misrepresentation.

Yet according to her paper Meyerson apparently wants to make just these attributions. What is more, she bases her account on a close reading of some of my publications, and sets out to back up her attributions with chapter and verse. How is it possible that she could have come to such conclusions regarding the views of "du Toit" on the basis of my own writings? Something has gone terribly wrong somewhere. Can it be that I have expressed my own approach and position so badly and misleadingly that a close reading of them could have brought Meyerson to construe a "du Toit" which I myself can just not recognise? It will be necessary to tum to the publications concerned and to consider to what extent they did or could provide grist to Meyerson's mill. At the same time this will involve something of a test case for the nature of Meyerson's own philosophical practice, enabling us to see to what extent this conforms to the relaxed and non-monolithic conception of analytical philosophy which she professes, or to what extent it exemplifies a different and narrower operative conception of analytical philosophy.

\section{Four}

It would be a long and, no doubt, otiose and boring undertaking to consider each and every one of Meyerson's attributions to "du Toit" with reference to the texts concemed. In the present context I do not have the time or space for this, and I must confine myself to some of the more pertinent cases and to a few general and background remarks. 
The first point to note is that Meyerson's account is wholly based on an extremely selective use of a small, incomplete and inadequate body of evidence. In toto it consists of some fragments from an article on "Philosophy in a changing plural society" which appeared in the first volume of the South African Journal of Philosophy in 1982, a few passages from my inaugural lecture of 1988 at UCT and an unpublished workshop paper of 1987. On this basis she finds it possible to extrapolate to a generalised account of the position of "du Toit" on a whole range of issues (and indeed uses that in turn as a stand-in for the critique of analytical philosophy in South Africa generally). This demonstrates a quite extraordinary approach to scholarship. No attempt has been made to check generalised attributions, based on one or other selective passage, against other parts or aspects of my work, even where this is clearly needed and would have been quite easy to do. Take the issue of intellectual history in South Africa as a problem of (post)colonial thought. The 1982 South African Joumal of Philosophy article and the inaugural lecture provide some passing references and brief discussions of Stockenström etc. These matters have been dealt with much more extensively in Afrikaner Political Thought (du Toit and Giliomee 1983) and a whole series of other publications, while my Politikon article (du Toit 1991b) and a recent article "On ideology" (du Toit 1994) made some attempt to address the underlying issues at a more theoretical and comparative level. It is a striking fenture of Meyerson's procedure that she makes no attempt at all to bring any of this into her account yet finds it possible to come to categorical conclusions regarding the positions of the "critic" concerned on the basis of just those selective passages utilised.

I suppose that there are various possibilities here. Meyerson may simply not be aware of any other relevant writings of her "critic" apart from the few texts she does utilise, a signal failure of research. More likely she simply sees no reason to consult any further material in the face of the, to her mind, definitive "evidence" provided by the particular texts she does adduce. If so, this would constitute a very peculiar principle of interpretation and argument, at variance with some of the most standard practices of historical, literary or juridical scholarship. Before condemning this out of hand, we should consider the possibility that it actually might be in accordance with her own conception of philosophical argument and analysis, as distinct from historical, literary or other kinds of textually based interpretation. On this view it would be possible and proper to establish an issue or discuss someone's position in abstraction from all further textual data or any relevant contextual considerations by simply focusing on the matter at hand and 
rigorously developing its logical implications. This is indeed an approach characteristic of analytical philosophy in its narrower and more purist guises, where "analysis" is essentially a piecemeal procedure, and effectively consists of mounting arguments and counter-arguments, in abstraction from any more holistic or contextual perspective. It might help to explain the otherwise inexplicable failures of elementary scholarship demonstrated in Meyerson's procedure: as an analytical philosopher she feels entitled to focus exclusively on the views and arguments entailed by some selected passage only, and to do this in ways that would be wholly unacceptable to historians, literary critics or, indeed, philosophers of less purely analytical persuasions. If so, it would also provide a significant indication whether Meyerson, in her own analytical practice, actually conforms to the relaxed conception of analytical philosophy which she professes, or reverts to a narrower and more purist approach.

Secondly it may be noted that Meyerson, in dealing with those few selective texts which she does discuss in order to establish the position of her "critic", proceeds with a striking disregard of the general and specific purposes of these particular writings themselves. It is of some consequence that the two publications on which she primarily relies to establish the position of her "critic" of analytical philosophy did not specifically set out to provide any such critique of analytical philosophy. They were rather concerned with different, though related and tangential, topics. It may come as something of a surprise to the reader of Meyerson's paper, but the fact of the matter is that the SAJP article (du Toit 1982) was not specifically concemed with the "relevance" of analytical philosophy in particular. That, of course, is Meyerson's topic. Instead, my article dealt with the more general question of the role and function of philosophy in the South African context. Moreover, it did so at a particular historical conjuncture and with distinctive objectives in mind. It was originally produced in 1976, written in the shadow of Soweto and with the impact and challenge of Biko and Black Consciousness very much in mind. The inaugural lecture (du Toit 1988a) was even less directly concerned with analytical philosophy or its relevance; instead, it set out to locate my own concerns as a philosopher in relation to the liberal tradition of justice and rights in the South African context. ${ }^{5}$

What Meyerson has done is to read these publications quite single-mindedly as if they were essentially concerned with her own topic of the "relevance" of analytical philosophy, and then to extrapolate from this material to some generalised "critique" of analytical philosophy. This ruthless disregard of the 
specific and stated objectives in the text can, of course, achieve startling results of interpretation. Thus in the $S A J P$ article I set out, writing very much as a South African philosopher, to provide a general self-critique of the nature and role of philosophy in the South African context. In the course of this general account various illustrations from, and passing comments on, analytical philosophy also figured. On Meyerson's version, that is by disregarding the functional context and by focusing on her selected aspects only, these passing commints and illustrations are construed as a hostile attack on analytical philosophy, thus giving an entirely different meaning to the text. For present purposes, though, it is the operative conception of analytical philosophy in Meyerson's own account which is instructive. On the basis of the relaxed and inclusive conception of analytical philosophy which she professes, she should have little difficulty in accepting the position articulated in this $S A J P$ article as entirely compatible with her own professed concerns as an analytical philosopher. Instead, she rejects this as a hostile attack against which analytical philosophy has to be defended. Once again, this strongly points to the conclusion that Meyerson's operative conception of analytical philosophy is in effect much more narrow than that professed in her paper.

Any conclusions regarding the precise nature of Meyerson's operative conception of analytical philosophy must, of course, depend on a more detailed consideration of her critical procedures. After all, it remains possible that, though the publications she adduces did not directly address Meyerscn's particular topic, they nevertheless provide sufficient evidence for her account of this "critic" of analytical philosophy. Consider this evidence, and Meyerson's use of it. Her most important source is the opening section of the 1982 SAJP paper which deals with the self-conceptions of their social and political responsibilities prevalent among contemporary philosophers. The article is concerned with such philosophical selfconceptions in general, but refers specifically to philosophers; who are "more or less analytically trained or even somewhat influenced by the heritage of Logical Positivism" (du Toit 1982:156). As illustrations of one such conception in particular, the paper refers to a well-known statement by Weldon from 1956 and a more incidental remark of Quine's in 1964. Meyerson quite rightly points out that this does not provide an adequate basis for generalisations regarding analytical philosophy as such, since these illustrations are taken from an earlier stage of analytical philosophy and the views concerned have in various ways become dated. This is quite correct - and was expressly so noted in the paper concerned. 
Immediately following the illustrations from Weldon and Quine, the following quite explicit qualification is made:

Obviously this sketch is an oversimplification even with regard merely to the world of Analytical and Positivist philosophy. The philosophical assumptions underlying these views are, in current philosophical debate, increasingly subject to revision and criticism (du Toit 1982: 157).

This is clear enough, and should surely serve to reassure Meyerson on this particular score. However, her account of "du Toit" based on this paper insists on the opposite, i.e. that these particular illustrations should be read as implying a generalised attack on analytical philosophy as such and in general. Did she then perhaps not notice the crucial qualification to the contrary? No, as a matter of fact she is actually well aware of it, and explicitly refers to "du Toit's...concession, at one point, that his description of the analytic commitment is simplistic" (Meyerson this volume:12). She even proceeds to quote the passage cited above, but only to dismiss this "concession" out of hand, essentially on the grounds that it does not fit the account of "du Toit" constructed in her paper (Meyerson this volume:12). This is circular reasoning with a vengeance indeed.

However, if Meyerson's handling of her evidence is transparently circular, it should not simply be dismissed for that reason. It is important to note quite carefully what is at stake here, since it reflects on Meyerson's own understanding of relevant changes in the nature and practice of analytical philosophy itself. The precise point at issue is that Meyerson first alleges that the SAJP article uses the dated positions of logical positivism and Weldon in order to come to generalised conclusions about analytical philosophy as such. When the text explicitly repudiates any such generalisations, she finds it "obscure" and "hard to know what to make of this argument" (Meyerson this volume:12) Why? Because it is said to be at variance with the generalised "conclusion" regarding analytical philosophy supposed to be based on the original illustrations. But this is precisely the issue at stake: there was no generalised argument regarding the nature of analytical philosophy involved in the use of the particular illustrations drawn from logical positivism and Weldon. The point is perfectly clear, and not at all hard to understand - unless, of course, one is operating with the assumption that any reference to analytical philosophy must involve implicit generalisations regarding its nature and, furthermore, that the correct view of this is to be found in some narrow and purist conception. There is no difficulty at all in referring to the self- 
conceptions of certain early analytical philosophers, and then to go on to wam that these should not be generalised to analytical philosophy as such, since later analytical philosophers have developed other views on these matters. This is the position taken in the $S A J P$ article, and it is a perfectly clear and coherent position as long as one is operating with a relaxed and contingent conception of analytical philosophy. However, if your operative conception of analytical philosophy is more narrowly drawn, and if you assume a more purist conception which does not allow for significant changes in the nature and practice of analytical philosophy itself, then references to early analytical philosophers must be consistent with whatever later developments are recognised. It is difficult to escape the conclusion that Meyerson's problems in making sense of this "concession" in the SAJP article are precisely due to such a narrow operative conception of the nature of analytical philosophy. ${ }^{6}$

The implicit shifts between Meyerson's professed inclusive and relaxed conception of analytical philosophy and her operative narrower and purist assumptions regarding it, if that is what they are, can also help to account for other striking features of her account of "du Toit" as the purported "critic" of analytical philosophy. Thus in the same context Meyerson is particularly concemed to stress the outdated nature of "du Toit's views" of analytical philosophy, more especially with regard to the logical positivist assumption of a sharp divide between conceptual investigation and empirical knowledge. She refers to this as "a startling distortion of the history of twentieth century Anglo-American philosophy" (Meyerson this volume:13). Citing the well-known work of Rawls and Dworkin, Meyerson finds it necessary to comment that

when even non-practitioners see the significance of the work of someone like Dworkin, as demonstrated by the feature article on his work in Time magazine...it is hard to understand how philosophers could come to say that contemporary analytical philosophy is reluctant to deal with social and political issues...These facts confirm just how outdated is du Toit's...version of analytical philosophy (Meyerson this volume:17-18).

In particular she feels called on to argue against the philosophical assumption that there is a sharp divide between conceptual investigation and empirical knowledge, a position which "du Toit" still outdatedly ascribes to analytical philosophy and apparently is also committed to himself (Meyerson this volume:13). Now Meyerson may be excused if she is unaware of the fact that this particular set of issues and developments were very much at the heart of 
my own teaching and research at the time, for example in the senior course I taught on "Analytical Social and Political Philosophy" at Stellenbosch. So far from being "outdated" this course probably constituted the most extensive treatment of these particular developments offered by any Philosophy department in South Africa at that stage. However, even if her account is based on the $S A J P$ article only, it could hardly have escaped her notice that it contains the following relevant passage:

The philosophical assumptions underlying these views are, in current philosophical debate, increasingly subject to revision and criticism. Quine himself would reject such a sharp dichotomy between empirical science and philosophical analysis, and it is well-known that the whole series of fundamental dichotomies such as the distinction between facts and values, first order language use and meta-analysis, observation sentences and theory construction, etc. have more and more come in for review and qualification. A new generation of younger philosophers, influenced by the later Wittgenstein and Winch, have set out to show that, properly understood, philosophical analyses of linguistic usage might have profound implications for philosophy and social theory (du Toit 1982:156).

The passage is relatively brief, and it was not further developed in the context of that article, but it is there and anyone specifically interested in this aspect could hardly fail to notice it. Indeed, Meyerson did notice this passage, and actually quotes it in full. So how can she ascribe actual ignorance of these later developments in analytical philosophy to her "critic" if they are explicitly referred to in the very article that she adduces as evidence? And how can she claim that this "critic" attributes such positions to analytical philosophy in general when she well knows that the inaccuracy of any such generalisation is explicitly acknowledged in the article in question? Well, the only answer we get is that "it is hard to know what to make" of the passage in question (Meyerson this volume:12). I am sorry, but it is not hard to understand what to make of these matters at all. Either this "critic" of analytical philosophy was ignorant of the relevant later developments, or he was not. And either he attributed the positivist disjunction between conceptual meaning and knowledge of empirical reality to analytical philosophers generally, or he did not. And on this the evidence in the article in question is quite clear for all to verify, and it does not support Meyerson's contentions. If this evidence is in conflict with the "conclusions" regarding analytical philosophy she attributes to her purported "critic", then she cannot just dismiss that evidence but will rather have to reconsider her own attribution of the alleged "conclusions" - 
unless of course the position of the purported "critic" is not a matter of evidence but an a priori construction driven by her own cperative conception of the nature of analytical philosophy.

Many more examples might be given of the peculiar and forced constructions Meyerson imposes on the evidence in the course of her defence of analytical philosophy against such uninformed and hostile "critics" as the "du Toit" she has constructed for this purpose. Thus in the conclusion of the SAJP article we find the following passage:

In the plural society of South Africa we may, in philosophy as well, no longer proceed ethnocentrically from an assumed unity of rationality in all processes of social consciousness. Rationality is not a direct gift from heaven, but it is a human cultural creation and hence can take different modifications (du Toit 1982:161).

In the original paper, of which her article is a revised version, Meyerson cited this and correctly observed that it raised the question of cultural relativism as a basic philosophical issue (Meyerson 1995:13-14). In this paper she went on to align the commitment to the unity of rationality with analytical philosophy, and suggested that the alternative position of cultural relativism must be based on "post-modernism" (Meyerson 1995:13). The clear suggestion was that "du Toit", as a "critic" of analytical philosophy, must be deriving his argument on the non-unity of rationality from post-modernist theory. As it happens, though, the passage concerned is virtually a direct quote from Winch's Idea of Social Science which, as is well-known, is explicitly based on the work of the later Wittgenstein, one of the dominant figures in the developrnent of analytical philosophy beyond its earlier logical positivist stage. The reference to Winch is clearly given in a footnote, which also provides a further reference to the volume on Rationality edited by Bryan Wilson, a standard work on this topic bringing together a number of seminal papers mainly by analytical philosophers (Wilson 1970). In other words, the passage in the SAJP article which Meyerson took pains to construe in terms of an alien deconstructionist critique of analytical philosophy is in fact quite clearly part and parcel of an internal debate within analytical philosophy itself. The point is that though there certainly might be room for disagreement and for philosophical debate on the unity of rationality and the implications for cultural relativism, there is no reason whatsoever to tum this into a confrontation between analytical philosophy and its "critics", as Meyerson for some strange reason insisted on doing. 
In the revised version of the current article Meyerson now concedes at least some of this. She admits that cultural relativism is not a post-modemist monopoly, but that this position is shared "even by some analytical philosophers" (Meyerson this volume:19). And she concedes that "this view does not represent an attack on analytical philosophy as such, which is why even analytical philosophers have been able to advance it" (Meyerson this volume:19). At first sight this might appear to be some sort of improvement, but on closer inspection it becomes clear that she has only compounded the confusion. Whereas her earlier position had the relevant facts all wrong, it did have a certain obstinate logic in ranging "du Toit" as a hostile and uninformed "critic" of analytical philosophy along with post-modem cultural relativists: on her account they shared a common opposition to that commitment to the unity of rationality supposed to be crucial to analytical philosophy. In the revised version, however, it is no longer clear what she is arguing either about "du Toit" as "critic", or about the commitments of analytical philosophy on this issue. As far as "du Toit" is concemed she now claims that "it is possible" that he holds a view, shared "even by some analytical philosophers", which might imply that analytical philosophy is a Eurocentric method (Meyerson this volume:19). However, this rather desperate scramble to square her argument with the admitted facts will not do. What, for instance, has happened to the uninformed and outdated nature of "du Toit" as "critic", if it now tums out that his views are shared "even by some analytical philosophers"? And what about those few heterodox analytical philosophers who hold these particular views - can they really be considered bona fide analytical philosophers? Well, actually no, it would seem. For in the very same sentence in which Meyerson concedes that "even some" analytical philosophers hold relativist views regarding rationality, she aligns this view with the alleged Eurocentricity of "the method so prized by analytical philosophers" (Meyerson this volume:19). One can only conclude that the dissident analytical philosophers concerned do not prize that method in the same sense, and that they are not to be taken seriously when it comes to circumscribing the compass of analytical philosophy in general. Conversely, it is clear that the analytical philosophers who prize the unity and universality of rationality, and who will have no truck with arguments which could lead to cultural relativism, provide the real point of reference for this particular discussion. In short, what we have here is the same sleight of hand in shifting from a professed relaxed and inclusive conception of analytical philosophy to a narrower and more purist operative conception of analytical philosophy when it really counts. 
One further example of the forced interpretations needed by Meyerson in order to arrive at her construction of "du Toit" as "critic" of analytical philosophy should suffice. In her original paper Meyerson made repeated use of a particular passage in the SAJP article to substantiate her claim that, according to "du Toit", analytical philosophers in general "see their brief in the thinnest possible way, as the elucidation of the 'logic' of this or that 'language game"" (Meyerson 1995:6). The passage in question is concerned with the relation that philosophy might have in the South African context to a social and political movement such as Black Consciousness, and reads as follows:

Indeed, philosophy as an academic discipline, as it is understood and professionally practised today by most philosophers in South Africa as well, can have little or nothing to do with a social and political movement such as Black Consciousness. Perhaps it might occasion an academic paper or two analysing the 'logic' of the particular political and ideological 'language game', or perhaps someone might attempt a more systematic analysis of the leading concepts in the Black Consciousness literature (du Toit 1982:159).

Two things should be noted here. First, the passage is quite evidently not concerned with a critique of analytical philosophy in particular, but with the condition of philosophy in general in the South African context. The critical charge, such as it is, is not directed to analytical philosophy in particular, but applies to South African philosophers in general - since I was writing as a South African philosopher myself this was also clearly meant as an exercise in self-critique, and not as an external critique from one philosophical vantage point directed at a rival philosophical position. Secondly, it should be noted that the passage amounts to a highly particular and contextualised judgement concerning the likely responses of South African philosophers to a phenomenon like Black Consciousness. It does not by any means amount to a programmatic argument whether (analytical) philosophy may, or may not, in theory be capable of any such applications. This is the way in which Meyerson insisted on taking this passage in her original paper but there seems to be no reason to do this - unless, of course, one first identifies philosophy tout court with analytical philosophy in particular, and secondly equates the programmatic prospects of analytical philosophy itself with the actual performance of South African philosophers. ${ }^{7}$ In short, Meyerson's use of this passage in her original paper had very little to do with its actual meaning and thrust in context; it had to be forced into a quite different set of arguments in 
order to arrive at her account of "du Toit" as the "critic" of analytical philosophy.

In the revised version of her article Meyerson has dropped all specific references to this discussion of the challenges posed by a phenomenon like Black Consciousness to South African philosophers including the analytical philosophers among them. Indeed, from her account the reader now would not know that the challenge of Black Consciousness constituted a central theme of the 1982 SAJP article. At the same time she has retained all the main contentions regarding the position of "du Toit" which had been built on this particular set of "evidence". The only difference is that she has now been careful to insert other verbatim quotes from the $S A J P$ article to provide ostensible backing for the same contentions. One must marvel at the impervious self-confidence of this procedure: if one piece of "evidence" for your conclusions will not do, well then simply find some other "evidence" as premises for the same conclusions. ${ }^{8}$ This amounts to exactly the converse of what Meyerson elsewhere terms the "guiding demand" in whose service all analytical writing is supposed to operate, i.e. the Socratic principle "to follow the argument where it leads" (Meyerson this volume:16). Meyerson's own procedure appears rather to conform conversely to what Bertrand Russell once termed the guiding demand of Scholastic reasoning, i.e. to fix on a set conclusion and then to find whatever grounds will serve to provide some sort of support for that.

In the mean time I may perhaps be permitted to wonder what became of the challenge of Black Consciousness to (analytical) philosophy in the South African context. For the purposes of my 1982 SAJP article this was an absolutely central concern. But on this Meyerson now maintains a total silence, while of course continuing to insist that analytical philosophy is potentially of great relevance in this very context. What are we to make of Meyerson's calculated silence on this front? Unlike Meyerson's benighted "critics", hardly anyone would want to dispute that analytical philosophy can potentially be of considerable relevance in all sorts of ways. To my mind, though, the concrete and contextualised question regarding the track record and imminent prospects of (analytical) philosophy in responding to particular challenges in the South African context is a much more interesting, and indeed urgent, question. Should we take Meyerson's silence on this issue to mean that she does not recognise this as an appropriate question in relation to her case for analytical philosophy? Or should we take it to mean that she does recognise this challenge, but implicitly concedes that a case cannot be made for analytical 
philosophy in such contextualised terms and with reference to the actual track record of analytical philosophy and its imminent prospects in the South African context? The answers to these concrete and contextualised questions would be much more revealing regarding the "relevance" of analytical philosophy on Meyerson's account than any number of misconceptions she might document regarding such misguided "critics" as "du Toit".

\section{Five}

A substantial part of Meyerson's article is given to a defence of the relevance of analytical philosophy to the South African context against charges from "critics" such as "du Toit" that it cannot have such relevance due to its universalist and ahistorical nature, and because it would involve the inappropriate application of "extraneous intellectual resources" in local contexts. To a considerable extent this discussion turns on the finer details of my treatment of Simkins and Rawls in my inaugural lecture. I have some difficulty in knowing how best to respond to this in the present context. On the one hand Meyerson's discussion of these matters raises a number of issues of genuine importance which have been central to much of my own work. The particular critical points she makes regarding my own accounts of Simkins and Rawls also merit a detailed and extensive response. If the space was available I would very much like to take her various substantive and critical points up on precisely these matters. However, the difficulty is that she is not primarily interested in Simkins or Rawls, or in my accounts of them, for their own sake. Rather, in her article all of this is in the service of a larger argumentative strategy, i.e. to rebut the unfounded charges levelled by the "critics" of analytical philosophy. It is for this purpose that "du Toit" once again figures so prominently on her pages. But it is less clear for precisely which general charges regarding the relevance of analytical philosophy in the South African context this "critic" is supposed to take responsibility on account of his treatment of Simkins and Rawls.

In her original paper a number of quite specific charges were levelled against "du Toit" in this regard. Thus it was alleged that "du Toit" holds such views as that, in the South African context, philosophers should not make any use of "extraneous intellectual resources" (Meyerson 1995:2,17,21 etc.), that philosophers in South Africa should confine themselves in their teaching and research to issues of local interest (Meyerson 1995:16-17), that the traditional 
curricula and research projects of analytical philosophy are out of place in South Africa (Meyerson 1995:16), and that political philosophy should be treated as a specialization without grounding in the core areas of mainstream philosophy (Meyerson 1995:22). By and large this was based on my criticisms of Charles Simkins' invocation of Rawls in the course of my inaugural lecture. In effect it amounted to an easily verifiable misrepresentation of my views on the basis of a total misreading of the specific purpose of my concern with Simkins' particular project of "reconstructing the liberal tradition" in South Africa, an enterprise by no means to be confused with mainstream theorising in philosophy or even in political philosophy. In the revised version of her article Meyerson has now dropped or substantially qualified all the specific attributions to "du Toit" noted above. She has also more correctly characterised my critical concerns with Simkins to be "in respect of work which attempts to reconstruct a particular local political tradition" (Meyerson this volume:22). As far as they go, these retractions are welcome and should help to clear the ground for more pertinent discussion. The problem remains, however, that if the more specific charges have been dropped, the overall argument somehow remains in place. The article still contains an extended discussion of my treatments of Simkins and Rawls which, apart from the more detailed points of specialist interest, somehow are still supposed to serve as a rebuttal of the unfounded views of this "critic" of analytical philosophy and its relevance in the South African context, even if it is no longer clear just what those views are supposed to be or just how they derive from my treatments of Simkins and Rawls.

I am afraid that this kind of discussion cannot serve any useful purpose. As a polemical strategy it is essentially unfair, and in general it merely serves to make confusion worse confounded. I will be more than happy to debate an accurate representation of my own views on the relevance of analytical philosophy in the South African context; I welcome any opportunity to discuss the problems of intellectual history and political traditions in a (post)colonial context such as that of South Africa; I am quite prepared to consider a detailed critique of my treatments of Simkins, including his invocation of Rawls and my own criticisms of that. But for the sake of intellectual order, let us please deal with each of these in its own right and proper context. The mixture concocted by Meyerson, in which a technical and detailed discussion of Rawls and Simkins serves as a stalking horse for vague and unspecified allusions regarding different matters in other contexts, is too heady a brew by far. 
In the present context I will confine myself to a few general remarks in response to Meyerson's evident confusion regarding my own views on the peculiar problems of intellectual history and political traditions in a (post)colonial context. According to Meyerson "du Toit" is committed to some utopian versicn of autochthonous philosophising in South Africa to the extent that she points to the "contradictions" involved in his own use of "extraneous intellectual resources". Thus she considers it a "puzzling feature" of "du Toit's" account that much is made of local figures like Stockenström etc. "when they were not, after all, building on the work of local thinkers but importing the idea of the rule of law from Britain" (Meyerson this volume:23). This amounts to a basic and double misunderstanding of the problems posed by a (post)colonial context for philosophy and local intellectual traditions as well as of the main thrust of my own work in this regard. The key feature of colonial intellectual history is precisely that in many different ways local traditions are not primarily the product of intemal social and political processes only. The colonial encounter precisely brings drastically divergent cultures together, and colonial history is marked by a series of extraneous interventions at both political and intellectual levels. The very idea that there can be something like a purely local or autochthonous intellectual tradition in a (post)colonial context is a contradiction in terms. My own work has been much concerned with just these features of intellectual history in South Africa. At the substantive level this has meant, from Afrikaner Political Thought on, a charting of the various ways in which local traditions are conceived and generated in and through an ongoing reception, transformation and perversion of, as well as interaction with, extraneous intellectual impulses and resources. At a more theoretical level I have reflected on some of the issues concerned in my Politikon article (du Toit 1991b). Taking my cue from, for example, Louis Hartz's fragmentation theory or Hobsbawm and Ranger's notion of "invented traditions", and more latterly from theories of "othering discourses" and the Comaroff's notion of a "colonisation of the mind", I have attempted to come to terms with the peculiarities of intellectual history in (post)colonial contexts. I think it is entirely appropriate that in doing so the theoretical approach adopted, as much as the subject matter itself, should be the product of a thorough mixing of both extraneous and local intellectual resources. This has also been a conscious striving in my theoretical work, and of applied interpretations in other contexts as well. I have consistently been an opponent of the prevailing tendency to South African "exceptionalism" in local political analysis and discussion. Thus, in the last few years, I have been active in introducing the 
comparative literature on transitions from authoritarian rule (O'Donnell and Schmitters etc.) to the analysis of the South African transition from apartheid. Similarly, I have been specifically concerned to locate the current South African debate on the proposed "Truth Commission" in relation to the international learning experience in Latin America and Eastem Europe in this regard. To my mind, there can be no question that any or all of this utilisation of "extraneous intellectual resources" might somehow be in tension with a concem with "local issues". Precisely in a (post)colonial context it is a radically false and misleading construction to pose these as mutually exclusive polarities, as Meyerson does via her extrapolation of "du Toit".

\section{Six}

I have by no means responded to all of Meyerson's strictures on "du Toit" as "critic" of analytical philosophy, including some to which her paper gives most attention. However, her remaining polemical targets may be said to fall into two main categories:

1) There are certain detailed critical discussions of passages like those on Chomsky and Quine in the 1982 South African Journal of Philosophy article demonstrating how they are supposed to have been misquoted or taken out of context. However, even if Meyerson should be wholly right on my alleged errors of interpretation regarding Chomsky etc., it would make no difference on the main issues considered above. Meyerson believes that I base large generalisations concerning analytical philosophy as such on these particular illustrations, in which case it would of course matter a great deal, at least for the purposes of her argument, that they are representative of analytical philosophy and that I get them right. But since I was not concemed to construct a generalised critique of analytical philosophy at all, and certainly not on the basis of these particular illustrations, this relevance falls away. I do believe that in these cases my interpretations can be defended, but this would involve extensive and complicated exercises in exegesis and I cannot see how this would make any difference to the overall argument. For these reasons I am leaving these cases unanswered even if I do not agree with Meyerson's specific contentions in this regard.

2) There are also some more substantive discussions on central issues in current political philosophy, such as the nature of Rawls' "ideal theory" and the implications of this for possible applications of his theory of justice to radically unjust societies, or the correct interpretation of liberal "neutrality". These are 
genuinely important issues, and well worth discussing in their own right. Again I believe that my own published positions on these issues are defensible, while Meyerson misrepresents both certain aspects of Rawls' theory and even more so my own alleged position on Rawls. Thus there is no reason to conclude, as Meyerson does, that I would make such an elementary error as to think that "there are some actually existing societies" to which Rawls' ideal theory apply while being irrelevant to other societies (Meyerson this volume:24). Similarly Rawls' notion of ideal theory in relation to basically just societies as distinct from radically unjust societies, like apartheid South Africa, is considerably more complex than appears from her account (Rawls 1972). But there is certainly space for altemative views and counter-arguments on these matters, and Lotter has made a good start in his recent Justice for an Unjust Society (Lotter 1993). Likewise, the issue of the meaning of liberal "neutrality" is a much more contested one than Meyerson will allow: liberal theorists like Rawls, Dworkin, Nagel and Ackerman have each developed subtly or more distinctively different positions in this regard. And it is still another matter again how all of this would apply to the kinds of questions regarding analytical philosophy which Meyerson wishes to address. This is really where the proper discussion with Meyerson should commence - the more is the pity that she has let so much unnecessary polemic get in the way that we will have to leave that debate to another occasion if we are to do it justice.

I have also not responded to the non-polemical sections of Meyerson's article in which she introduces relevant perspectives on some of the issues at stake via analogies with feminist arguments etc. There is much of interest in these parts of her article, but these cannot be pursued in the present context. I will thus simply conclude by briefly indicating where I think the real issues between myself and Meyerson lie, once all the straw men cluttering the landscape have been cleared out of the way.

\section{Seven}

It should be clear by now that Meyerson's beleaguered defences of analytical philosophy against its South African "critics" are quite unnecessary and fundamentally misconceived. She may rest assured that the catholic and nonmonolithic kind of analytical philosophy espoused by her in this paper will, if genuine, find few, if any, real critics. Others, like myself, will be only too willing to join with her in thinking through how (analytical) philosophy could be made more "relevant" in the South African context. Even then, though, 
there should be room for critical discussions of the role and assumptions of philosophy and philosophers in South Africa, not excluding analytical philosophy and analytical philosophers. Meyerson and myself may well find ourselves on different sides of various critical issues in this regard. However, if critical discussions and possibly even polemical exchanges are to generate light rather than heat and confusion, some basic distinctions will have to be bome in mind.

Firstly, there is a fundamental difference between external and internal (self)criticism. While the former proceeds from divergent assumptions and may have essentially negative aims, the latter actually assumes common ground and may have constructive aims in terms of shared values and criteria. When internal critics are cast as necessarily external and hostile this can lead to serious problems of communication.

Secondly, there is a fundamental difference between a programmatic critique (or defence) of a philosophical approach and particular contextualised judgements of its practitioners. It is one thing to enter in discussion on the potential prospects for and/or limitations of analytical philosophy in general; it is another thing to make a critical assessment of the actual performance and prospects of (analytical) philosophers in a particular setting. It is entirely possible that, while in programmatic terms analytical philosophy could be argued to have great potential relevance in the South African context, the actual state of analytical philosophy in South Africa might still leave a great deal to be desired. And it would not be adequate to respond to criticism on the latter front merely by shifting the ground to programmatic discussions.

Thirdly, if we are to engage in comparative and critical discussions of different philosophical approaches, then it will be necessary to retain a proper sense of the distinctiveness of each, i.e. their specific contributions and limitations, even while remaining open to the extent to which they might share common philosophical ground. There are ways in which analytical philosophy, compared to other philosophical approaches, is specifically limited as well as distinctively rigorous. A defence of analytical philosophy which merely insists on the ways in which it is part of the philosophical mainstream, and which does not face up to its distinctive limitations, may actually amount to a disguised form of philosophical imperialism. ${ }^{10}$

Bearing in mind these distinctions, it may be possible to identify where the actual quarrel, if any, between myself and Meyerson lies, or in what sense it may 
be necessary for her to defend analytical philosophy against me and others as internal or external critics.

At the outset I said that I found the catholic and non-monolithic conception of analytical philosophy which Meyerson professes attractive and that I welcomed the basic thrust of her concern that this could be shown to be "relevant" to local issues in the South African context (even if the notion of "relevancy" needed to be further unpacked). I do think that there is more common ground between us than major philosophical differences, if she can only let go of her polemical obsessions with "du Toit" and the "critics" of analytical philosophy. But there also appear to be genuine philosophical differences involved, and these should at least be identified here for possible future discussion.

One set of possibly contentious issues concerns the way in which the nature of the South African intellectual context is conceptualised in relation to the mainstream Western tradition of philosophy. Meyerson claims that

analytical philosophy has, at its best, enormous power to illuminate and impact on our local situation (Meyerson this volume:1).

But just what is the relevant meaning and implications of "local" in this context? I would argue that, fully unpacked, the meaning and implications of "local" would require us to reflect on the (post-)colonial, as opposed to the provincial, nature of South African intellectual traditions. It is not clear whether Meyerson recognises what is involved in this distinction when she writes that

the fact is that all South African social theorists and philosophers, of whatever persuasion, are working in the same context and face the same problem: we depend inevitably on overseas work and we need to be sensitive to the problems created by that (Meyerson this volume:28).

A great deal will depend on the precise burden of the adjective "overseas" in this sentence (i.e. whether or not it is taken to imply a colonial condition and history). Is the position of South African philosophers essentially similar to those of their colleagues in, say, the English or French provinces, or perhaps in Oklahoma, or is there an important and relevant difference between their respective intellectual situations in relation to the metropolitan mainstream? ${ }^{11}$ My suspicion is that Meyerson assumes that "local" is to be taken in the provincial rather than the (post-)colonial sense. This has important philosophical implications and has everything to do with Meyerson's 
discussion of the Eurocentric assumption of the unity of rationality and the dangers inherent in cultural relativism (Meyerson this volume:22f). Here there certainly are ample grounds for philosophical debate, and I suspect that Meyerson will not easily be persuaded by my analysis of the implications of a (post-)colonial intellectual history for the practice of philosophy itself. But this is by no means to be confused with a critique or a defence of analytical philosophy - as indicated above the issue of the unity of rationality is also very much an internal philosophical dispute within analytical philosophy itself. Likewise I think that this set of issues is also relevant to Meyerson's alternative exegesis to my own of Rawls on "ideal theory" and liberal "neutrality". At one level her critical comments on my own accounts in this regard require a standard exegetical response: we will have to go back to the details of Rawls' texts and thrash out how his arguments are best to be construed. At another level, though, the specific issues concerned here have a direct bearing on the problem of making philosophy "relevant" to the South African context. In this regard, I have already referred to the suggestive study by Hennie Lotter, Justice for an Unjust Society (Lotter 1993), in which he has taken on precisely these issues.

The second set of genuinely contested issues concerns the precise relation of philosophy to social and political practice. Meyerson wants to argue that (analytical) philosophy "has, at its best, enormous power to illuminate and impact on our local situation" (Meyerson this volume:1, emphasis added; note that the emphasised words here amount to a much stronger claim than would be involved in "illumination" only). Meyerson not only maintains that (analytical) philosophy can and should provide accessible analyses of local and concrete issues. She also wants to argue that it has "enormous potential to alter substantive beliefs" (Meyerson this volume:14), and that it may legitimately be expected to "contribute positively to social transformation" (Meyerson, this volume:9, emphasis added). These are large and general claims which need to be unpacked, and it is unclear just how far Meyerson would be prepared to go along with some possible implications. Thus by way of example of what she has in mind, Meyerson refers to the impact of a rigorous analysis of the conceptual logic of rights discourses on those who tend to endorse notions of "rights" naively and uncritically:

This shows how the elucidation of meanings may have important political implications... when the notion [of "rights"] is elucidated those who merely mouthed 
position" (Meyerson this volume:17, emphasis added).

Two comments are in order here. First, this seems to assume an excessively rationalist view of the relation between thought and social or political conduct. ${ }^{12}$ Secondly, it needs to be pointed out that changes in political views and attitudes, or in substantive beliefs, even where these do take place, are still a considerable way short of what is commonly understood by social transformation. I am afraid that Meyerson tends to use the word "transformative" rather loosely. She asks "how could it be other than transformative to engage in an activity [of critical analysis]" (Meyerson this volume:16), and claims that she could give "innumerable examples of analytical work with transformative political and social significance" (Meyerson this volume:17). However, the examples provided stay strictly within the academic realm and at best concern the implications of theoretical analysis for applied ethics. What is missing here is any strong sense for the problems involved in what used to be called the relation between theory and practice. (Bernard Williams and Mary Warnock chairing national commissions does not necessarily indicate that a satisfactory solution to this basic problem has been found). It would seem that this might also be part of the explanation for Meyerson's inability to comprehend the sense in which I am prepared to "concede" that the account of (analytical) philosophy in my $1982 S A J P$ article is an oversimplification, but nevertheless continue to maintain that later and more sophisticated versions of analytical philosophy share similar philosophical self-conceptions. Though readily conceding that "philosophical analyses of linguistic usage might have profound implications for political philosophy and social theory", I wrote, "the decisive question remains whether philosophy has any consequences for social and political practice" (du Toit 1982:157, emphasis added). The decisive question, in other words, concerns the relation of theory to practice. I argued that, even if one took into account the later developments in analytical philosophy which closed the assumed gap between conceptual meaning and substantive empirical knowledge, the self-conception of the philosophers concerned essentially remained that of philosophy as an analytical and theoretical activity. In this respect there are crucial differences between analytical philosophers and the Hegelian and Marxist traditions in philosophy. If one has an attenuated sense of what the question of social and political practice involves, or if one tends to equate the logical "implications" of theoretical analyse:s and conceptual 
investigations with their social and political "consequences", then the point of my argument here will probably remain elusive. This is not necessarily a question of individual obfuscation. There may be genuine philosophical differences involved, and it is an interesting question to what extent the problem of theory and practice can even be raised within certain rationalist traditions of philosophy. This is the point where my argument for a more Hegelian approach to the relation between philosophy and social and political consciousness would begin, and it may be the point where Meyerson as analytical philosopher comes to the limits of her philosophical tolerance.

So we do have genuine issues to debate, and there may be underlying philosophical disagreements to confront - but please, let us first get rid of fabricated polemics against "du Toit" and other supposed "critics" of analytical philosophy. Who needs them, anyway?

\section{Notes}

1 One sometimes gets the impression that there is more active interest and debate on current philosophical developments outside philosophy departments. In this regard is instructive that Theoria, currently the best journal of philosophy and social theory in South Africa, is not published from a Philosophy department

2 Denisc Mcycrson, "Analytical philosophy and its South African critics", Social Dynamics 21(1) (1995):57-87.

3 Similarly, in the UCT Politics department, I currently teach a survey course on theories and critics of human rights, ranging from Hobbes, Locke and Bentham through Marx to Rawls, Dworkin and Nozick as a core course in the political philosophy Honours programme.

4 Thompson is not a "pure" analytical philosopher, but the kind of Cambridge philosopher engaging with Continental theory which Meyerson's catholic and nonmonolithic view of analytical philosophy would surely welcome.

5 The unpublished workshop paper - du Toit, 1987 - actually did set out to say some sharply critical things involving the practice of analytical philosophy in South Africa. However, this critique very specifically concerned issues connected with the objectives, practice and promotion of the journal Philosophical Papers at that time, and was not generalised to analytical philosophy as such. 
6 I will return in the concluding section to another way in which Mcycrson's apparent inability to grasp what is at stake here may be due to certain inherent limitations of analytical philosophy itself, more specifically with regard to the problem of theory and practice.

7 In the latter case it would presumably be highly relevant to inquire whether my judgement at the time held true: how did (analytical) philosophers in South Africa respond to the phenomenon of Black Consciousness? Alnost twenty years on I am not aware, apart from this South African Journal of Philosophy article itself and a recent piece by Hennie Lotter, of substantial philosophical responses on this front.

8 As a matter of fact the new quotations arc taken from the same discussion of illustrations drawn from earlier analytical philosophers which have already been dealt with above, and are once more used out of context to support purported generalisations regarding analytical philosophy as such which a closer examination will simply not bear out.

9 Note, once more, how this construction proceds: in her account of my position on this topic Meyerson is quite ready to extrapolate from the occasional remark on Stockenström, and sees no need to consult the more systematic discussions even where these are directly relevant and easily available.

10 The assertion that analytical philosophy is mercly the continuation in the twentieth century of the classical mainstream tradition which goes back to the Greeks could then be taken to imply, conversely, that non-analytical philosophy does not belong to that mainstream.

11 When General Smuts famously referred to South Africa as "this far-flung corner of the world" he essentially conceptualised the South African situation in provincial terms, denying its (post-)colonial condition.

12 Mcycrson refers to "dccply buricd assumptions [which] fecd into action, and if they do not survive scrutiny neither will the patterns of behaviour which they inform" (Meyerson this volume:72, emphasis added). Both psycho-analysts, on the one hand, and sociologists and political scientists, on the other hand, are bound to have plenty of problems with this simplistic model of social action. 


\section{Works Cited}

Ayer, A.J. 1936. Language, Truth and Logic. London: Gollancz.

Du Toit, A. 1974. "Logic and ontology: Russell's logical methods for philosophy prior to 1905". Philosophical Papers 3:17-45.

Du Toit, A. 1982. "Philosophy in a changing plural society". South African Journal of Philosophy 1:154-161.

Du Toit, A. 1983. "The Critique of psychologism in its historical and philosophical setting". South African Journal of Philosophy 2: 72-84.

Du Toit, A. 1987. "Workshop: philosophy in South Africa". Unpublished paper, University of Cape Town.

Du Toit, A. 1988a. "Justice and Truth in South Africa?" Inaugural lecture, University of Cape Town.

Du Toit, A, 1988b. "Understanding rights discourses and ideological conflicts in South Africa". In H.Corder (ed.), Essays on Law and Social Practice. Cape Town: Juta:237-265.

Du Toit, A. 1991a. "Legitimate anachronism as a problem for intellectual history and philosophy". South African Journal of Philosophy $10: 87-95$.

Du Toit, A. 1991b. "The problem of intellectual history in (post-) colonial societies: The case of South Africa". Politikon 18:5-25.

Du Toit, A. 1994. "On ideology". South African Journal of Philosophy 13:111-117.

Du Toit, A. and Giliomee, H. 1983. Afrikaner Political Thought: Documents and Analysis. Vol. 1: 1780-1850. Cape Town: David Philip.

Flathman, R.(ed.) 1973. Concepts in Social and Political Philosophy. London: Collier-MacMillan.

Kierkegaard, S. 1957. The Concept of Dread, tr. Walter Lowrie.

Princeton: Princeton University Press.

Lotter, H.P.P. 1993. Justice for an Unjust Society. Amsterdam: Rodopi.

Meyerson, D. 1995. "Analytical philosophy and its South African critics". Africa Seminar paper, Centre for African Studies, University of Cape Town.

Miller, S. and MacDonald, I. 1990. "Philosophy in South Africa: A reply to Robert Paul Wolff'. The Philosophical Forum XXI(4):442-450.

Pitkin, H. 1972. Wittgenstein and Justice. Berkeley: University of California Press.

Rajchman, J. and West, C. (eds) 1985. Post-Analytical Philosophy. New York: Columbia University Press. 
Rawls, J. 1972. A Theory of Justice. Oxford: Oxford University Press.

Rorty, R. (ed.) 1967. The Linguistic Turn: Recent Essays in

Philosophical Method. Chicago: University of Chicago Press.

Thompson, J.B. 1984. Studies in the Theory of Ideology. Cambridge:

Polity Press.

Tully, J. (ed.) 1988. Meaning and Context: Quentin Skinner and His Critics. Princeton: Princeton University Press.

Wilson, B.R. (ed.) 1970. Rationality. Oxford: Blackwell.

Winch, P. 1958. The Idea of a Social Science and its Relation to

Philosophy. London: Routledge and Kegan Paul.

Wolff, R.P. 1986-7. "Philosophy in South Africa". The Philosophical

Forum 18: 94-104. 